\title{
The status of dermatoglyphics as a biomarker of Tel Hashomer camptodactyly syndrome: a review of the literature
}

\author{
Buddhika T. B. Wijerathne ${ }^{1 *}$, Robert J. Meier ${ }^{2}$ and Suneth B. Agampodi ${ }^{1}$
}

\begin{abstract}
Introduction: Tel Hashomer camptodactyly syndrome is a rare disease and only a few cases have been reported. Dermatoglyphics potentially provide relevant phenotypic biomarkers that were initially noted as a vital clinical feature of this disease. Dermatoglyphics possibly can indicate growth disturbances that took place during early fetal development at the time when epidermal ridges were being formed into discernable patterns. Consequently, these intrauterine effects might well have occurred in association with the expression of the Tel Hashomer camptodactyly syndrome. Therefore, this review was undertaken to provide, as far as we know, the first attempt to broadly assess dermatoglyphic features that are connected with the Tel Hashomer camptodactyly syndrome. If a developmental association between dermatoglyphics and Tel Hashomer camptodactyly can be firmly established, this would probably document that Tel Hashomer camptodactyly disease has its origins during the early fetal period.
\end{abstract}

Methods: A systematic literature search was conducted using articles from PubMed (Medline), POPLINE, Trip Database, Cochrane Library, and gray literature up to 31 March 2015. The review was performed according to the Preferred Reporting Items for Systematic Reviews and Meta-Analyses statement.

Results: Fourteen relevant publications were included in the review. There were 23 cases of patients with Tel Hashomer camptodactyly syndrome that were described in these published articles. We reviewed the dermatoglyphics of 21 available cases out of all of the published and electronically available cases of Tel Hashomer camptodactyly. Eight cases reported whorls to be the most common digital pattern with an expected rise of ridge count. Two cases show significantly high frequencies of arch patterns. Further, there were increased numbers of palmar creases, along with abnormal flexion creases or other palmar dermatoglyphic abnormalities reported in all cases.

Conclusion: This review highlighted the desirability of thoroughly observing and recording dermatoglyphic features when reporting on future patients with Tel Hashomer camptodactyly syndrome, in conjunction with carrying out modern molecular methods.

Keywords: Tel Hashomer camptodactyly syndrome, Dermatoglyphics, Camptodactyly

\section{Introduction}

Tel Hashomer camptodactyly (THC) syndrome is a rare disease first termed by Goodman et al. in 1976 after examining two sisters with camptodactyly [1]. Earlier in 1972, they reported two brother and sister pairs having similar clinical features [2]. Up to the present time, a literature search has found only 23 cases. THC is mainly

\footnotetext{
* Correspondence: buddhikatbw@gmail.com

'Department of Community Medicine, Faculty of Medicine and Allied

Sciences, Rajarata University of Sri Lanka, Saliyapura 50008, Anuradhapura, Sri

Lanka

Full list of author information is available at the end of the article
}

characterized by the presence of camptodactyly with muscular hypoplasia and weakness, skeletal dysplasia, facial dysmorphism (facial asymmetry, small mouth, broad nasal bridge, long philtrum, and hypertelorism), and abnormal dermatoglyphics: Online Mendelian Inheritance in $\mathrm{Man}^{\circ}$ (OMIM) \#211960, The portal for rare diseases and orphan drugs (ORPHA) 3292 [3, 4]. In addition, mitral valve prolapse, spina bifida, scoliosis, inguinal hernia, winging scapulae, clubbed feet, syndactyly and clinodactyly were

(c) 2016 Wijerathne et al. Open Access This article is distributed under the terms of the Creative Commons Attribution 4.0 International License (http://creativecommons.org/licenses/by/4.0/), which permits unrestricted use, distribution, and reproduction in any medium, provided you give appropriate credit to the original author(s) and the source, provide a link to the Creative Commons license, and indicate if changes were made. The Creative Commons Public Domain Dedication waiver (http://creativecommons.org/publicdomain/zero/1.0/) applies to the data made available in this article, unless otherwise stated. 
indicated as clinical features $[3,4]$. THC is considered to be a disease with autosomal recessive inheritance [5]. Mochizuki et al. [6] recently reviewed the molecular characteristics of a patient described by Toriello et al. in 1990 [7] and suggested that at least several cases of THC may actually be Ehlers-Danlos syndrome.

Goodman et al. [1] stated the importance of dermatoglyphic biomarkers as clinical features when diagnosing THC. Dermatoglyphic characters that need to be present to diagnose THC are: (a) presence of seven or more whorls on digits (these whorls extend beyond the borders of the terminal phalanges), (b) low main line index, caused by the highly vertical orientation of the A to D radiants, and (c) numerous palmar creases that obliterate the normal structure of the ridges and openings of the sweat pores. We systematically analyzed all published cases of THC syndrome to describe the importance of dermatoglyphics in diagnosing this rare disease.

\section{Methods}

The review has been conducted and reported using the Preferred Reporting Items for Systematic Reviews and Meta-Analyses (PRISMA) statement guidelines [8].

\section{Search strategy}

We conducted a search of the literature for articles indexed in PubMed $^{\circ}$ (Medline), POPLINE, TRIP Database, and Cochrane Library database, from earliest dates to 31 March 2015. In addition, we searched the gray literature sources of Google Scholar, OpenGrey, and Google, from earliest date to 31 March 2015. The reference lists of the studies selected were manually searched for any relevant studies. We did not restrict the searches based on language or publication status. The following terms were used to search the literature: "Tel Hashomer camptodactyly", "Tel Hashomer camptodactyly syndrome."

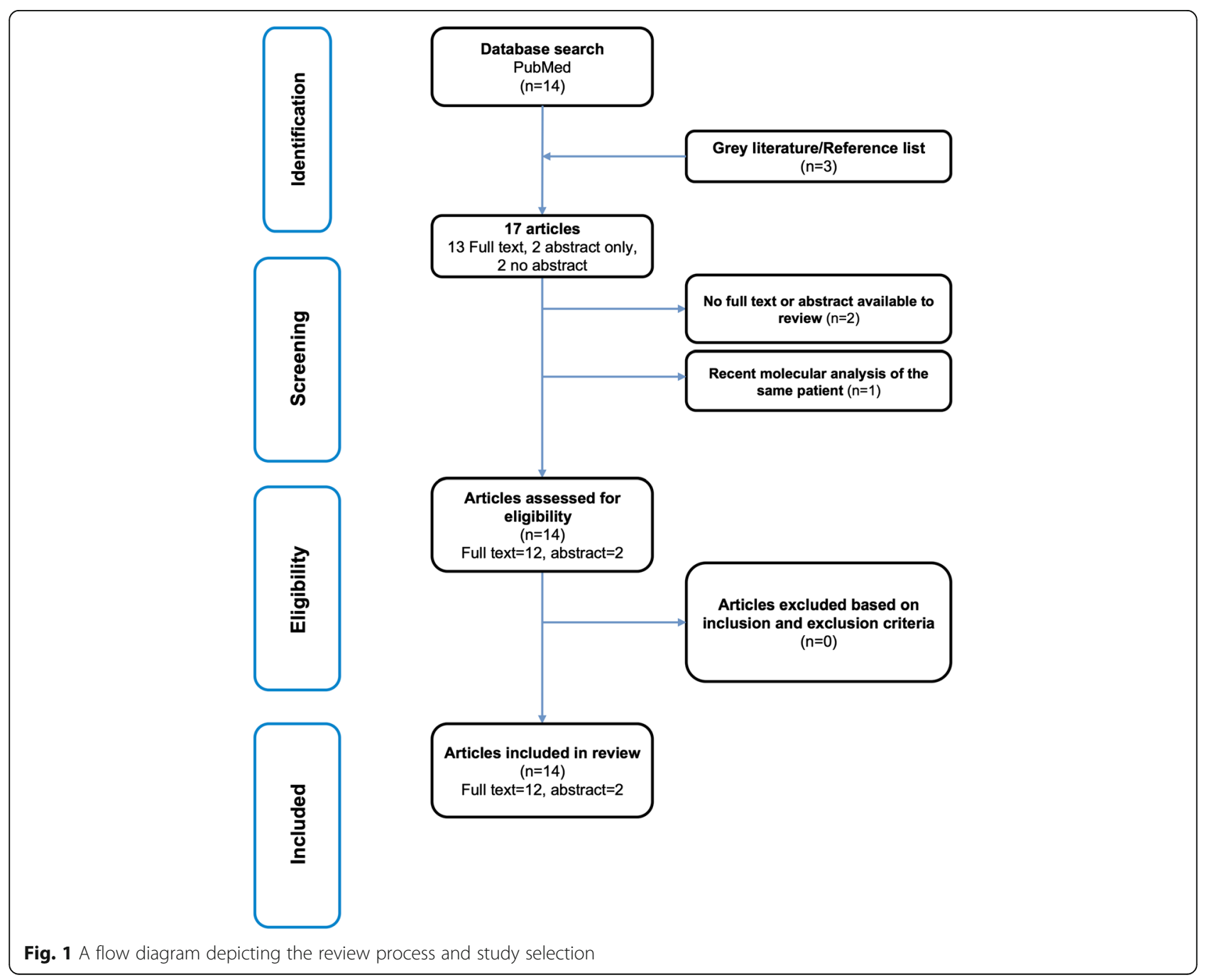


Table 1 Dermatoglyphic features of published cases of Tel Hashomer camptodactyly syndrome

\begin{tabular}{|c|c|c|c|}
\hline Author and year & Disease diagnosis & $\begin{array}{l}\text { Demography (age, sex, } \\
\text { consanguinity, ancestry/lineage, } \\
\text { country of case reported) }\end{array}$ & Dermatoglyphic features \\
\hline \multirow[t]{2}{*}{$\begin{array}{l}\text { Goodman et al., } \\
1972 \text { [2] }\end{array}$} & \multirow[t]{2}{*}{$\begin{array}{l}\text { Camptodactyly with muscular } \\
\text { hypoplasia, skeletal dysplasia, } \\
\text { and abnormal palmar creases } \\
\text { Clinically diagnosed }\end{array}$} & $\begin{array}{l}\text { 17-years old } \\
\text { Female (Proposita) } \\
\text { No consanguinity } \\
\text { Jewish Moroccan ancestry } \\
\text { Reported from Israel }\end{array}$ & $\begin{array}{l}\text { Digital dermatoglyphics: } \\
\text { Whorls }=8 \text { and extended beyond the borders } \\
\text { of the terminal phalanges, TRC high }=271 \\
\text { Palmar dermatoglyphics: } \\
\text { A-b ridge count }=73 \text {, ridge breath }=606 \text {, maximal } \\
\text { atd angle }=110.5 \text {, modification of creases }\end{array}$ \\
\hline & & $\begin{array}{l}\text { 13-years old } \\
\text { Male (affected brother) } \\
\text { No consanguinity } \\
\text { Jewish Moroccan ancestry } \\
\text { Reported from Israel }\end{array}$ & $\begin{array}{l}\text { Digital dermatoglyphics: } \\
\text { Whorls }=8 \text { and extended beyond the borders of } \\
\text { the terminal phalanges, TRC high }=350 \\
\text { Palmar dermatoglyphics: } \\
\text { A-b ridge count }=120 \text {, ridge breath }=536 \text {, maximal } \\
\text { atd angle }=101.0 \text {, modification of crease }\end{array}$ \\
\hline \multirow[t]{2}{*}{$\begin{array}{l}\text { Goodman et al., } \\
1976 \text { [1] }\end{array}$} & \multirow[t]{2}{*}{$\begin{array}{l}\text { Tel Hashomer camptodactyly } \\
\text { syndrome } \\
\text { Clinically diagnosed }\end{array}$} & $\begin{array}{l}\text { 20-years old } \\
\text { Female (Proposita) } \\
\text { Consanguineous parents } \\
\text { Bedouin } \\
\text { Reported from Israel }\end{array}$ & $\begin{array}{l}\text { Digital dermatoglyphics: } \\
\text { Whorls }=9 \text {, TRC high }=177 \\
\text { Palmar dermatoglyphics: } \\
\text { A-b ridge count }=77 \text {, ridge breath }=493, \text { maximal } \\
\text { atd angle }=75, \text { modification of crease }\end{array}$ \\
\hline & & $\begin{array}{l}\text { 19-years old } \\
\text { Male (affected brother) } \\
\text { Consanguineous parents } \\
\text { Bedouin } \\
\text { Reported from Israel }\end{array}$ & $\begin{array}{l}\text { Digital dermatoglyphics: } \\
\text { Whorls }=7, \text { TRC high }=209 \\
\text { Palmar dermatoglyphics: } \\
\text { A-b ridge count }=76 \text {, ridge breath }=697 \text { maximal } \\
\text { atd angle }=92, \text { modification of crease }\end{array}$ \\
\hline \multirow[t]{2}{*}{$\begin{array}{l}\text { Gollop and Colletto } \\
1984 \text { [9] }\end{array}$} & \multirow[t]{2}{*}{$\begin{array}{l}\text { Tel Hashomer camptodactyly } \\
\text { syndrome } \\
\text { Clinically diagnosed } \\
\text { Normal female chromosome }\end{array}$} & $\begin{array}{l}\text { 7-years old } \\
\text { Female (Proposita) } \\
\text { Consanguineous parents } \\
\text { Brazilian } \\
\text { Reported from Brazil }\end{array}$ & $\begin{array}{l}\text { Digital dermatoglyphics: } \\
\text { Arches }=6, \text { whorl }=2, \text { ulnar loop }=2 \\
\text { TRC }(\mathrm{LH}=11, \mathrm{RH}=14) \\
\text { Palmar dermatoglyphics: } \\
\text { Bilateral transverse palmar crease, numerous } \\
\text { additional palmar creases, vertical orientation } \\
\text { of lines a and } \mathrm{t} \text {, left hand the ulnarity index } \\
\text { of patient } 1 \text { was decreased }(0.51 \text {; mean Brazilian } \\
\text { normal value } 0.79 \text { and } 0.08, \mathrm{a}-\mathrm{b} \mathrm{RC}(\mathrm{LH}=33, \mathrm{RH}=32) \text {, } \\
\text { a-d } \mathrm{RC}(\mathrm{LH}=44, \mathrm{RH}=45) \text {, atd angle }(\mathrm{LH}=40, \mathrm{RH}=35) \text {, } \\
\text { main line index }=(\mathrm{LH}=7, \mathrm{RH}=7)\end{array}$ \\
\hline & & $\begin{array}{l}\text { 9-years old } \\
\text { Male (affected brother) } \\
\text { Consanguineous parents } \\
\text { Brazilian } \\
\text { Reported from Brazil }\end{array}$ & $\begin{array}{l}\text { Digital dermatoglyphics: } \\
\text { Arches }=9 \cup L 1, T R C(L H=0 R H=1) \\
\text { Palmar dermatoglyphics: } \\
\text { Bilateral transverse palmar creases, numerous white } \\
\text { lines, and vertical orientation of lines a and } t \text {, the } b \\
\text { triradius is absent and the atd angle is increased } \\
\text { owing to a rare ulnar loop present in the hypothenar } \\
\text { region at the level of the transverse palmar crease } \\
\text { A-b } R C=(L H=0, R H=42), a-b R C=(L H=64, R H=66) \text {, } \\
\text { atd angle }(L H=107, R H=106), \text { main line } \\
\text { index }=(L H=5, R H=7)\end{array}$ \\
\hline
\end{tabular}

Tylki-Szymanska Tel Hashomer camptodactyly 13-years old 1986 [10] syndrome

Clinically diagnosed
Female (Proposita)

Consanguineous parents

(first cousins)

Libyan family

Reported from Poland

13-years old

Male (Proposita)

Consanguineous parents

(first cousins)

Libyan family

Reported from Poland

10-years old

Female (Proposita)

Consanguineous parents

(first cousins)

Libyan family

Reported from Poland 
Table 1 Dermatoglyphic features of published cases of Tel Hashomer camptodactyly syndrome (Continued)

\begin{tabular}{|c|c|c|c|}
\hline $\begin{array}{l}\text { Patton et al., } \\
1986[11]\end{array}$ & $\begin{array}{l}\text { Tel Hashomer camptodactyly } \\
\text { syndrome } \\
\text { Clinically diagnosed }\end{array}$ & $\begin{array}{l}\text { 4-years old } \\
\text { Female (Proposita) } \\
\text { No consanguinity } \\
\text { Mother was English and } \\
\text { father was Anglo-Asian origin } \\
\text { Reported from UK }\end{array}$ & $\begin{array}{l}\text { Palmar dermatoglyphics: } \\
\text { Absent or decreased interphalangeal creases }\end{array}$ \\
\hline $\begin{array}{l}\text { Pagnan et al., } \\
1988[12]\end{array}$ & $\begin{array}{l}\text { Tel Hashomer camptodactyly } \\
\text { syndrome } \\
\text { Clinically diagnosed } \\
\text { Karyotype: chromosomes } \\
\text { were normal }(46, X X)\end{array}$ & $\begin{array}{l}\text { 41/2-years old } \\
\text { Female (Proposita) } \\
\text { No consanguinity } \\
\text { Ancestry : NR } \\
\text { Reported from Brazil }\end{array}$ & $\begin{array}{l}\text { Digital dermatoglyphics: } \\
\text { Whorls 10/10, digital patterns are large, with } \\
\text { displacement of triradii, TRC }=350 \\
\text { Palmar dermatoglyphics: } \\
\text { A-b RC = 95, maximal atd } 108.5 \text {, a-d count }=97 \text {, } \\
\text { MLI = 16, modification of crease, simian crease } \\
\text { of left hand, many "white } \\
\text { lines" (shallow grooves of different length, width, } \\
\text { and direction) on both palms and fingers and } \\
\text { vertical orientation of the } a, b \text {, and t lines on the } \\
\text { right and left hand }\end{array}$ \\
\hline \multirow[t]{2}{*}{$\begin{array}{l}\text { Toriello et al., } \\
1990[7]\end{array}$} & $\begin{array}{l}\text { Tel Hashomer camptodactyly } \\
\text { Clinically diagnosed }\end{array}$ & $\begin{array}{l}\text { 151/2-years old } \\
\text { Male (Proposita) } \\
\text { Consanguinity: NR } \\
\text { Hispanic } \\
\text { Reported from USA }\end{array}$ & $\begin{array}{l}\text { Digital dermatoglyphics: } \\
\text { Large whorls on each digit } \\
\text { Palmar dermatoglyphics: } \\
\text { A-d triradii, vertical a, b, and t lines, multiple } \\
\text { white lines, and } 2 \text { palmar whorls on each hand }\end{array}$ \\
\hline & & $\begin{array}{l}\text { 11-years old } \\
\text { Female (younger sister) } \\
\text { Consanguinity: NR } \\
\text { Hispanic } \\
\text { Reported from USA }\end{array}$ & $\begin{array}{l}\text { Digital dermatoglyphics: } \\
9 \text { large whorls and } 1 \text { ulnar loop } \\
\text { Palmar dermatoglyphics: } \\
\text { A triradius, vertical } a \text {, b, and t lines, and multiple } \\
\text { white lines }\end{array}$ \\
\hline $\begin{array}{l}\text { Franceschini } \\
\text { et al., } 1993 \text { [13] }\end{array}$ & $\begin{array}{l}\text { Tel Hashomer camptodactyly } \\
\text { syndrome } \\
\text { Clinically diagnosed }\end{array}$ & $\begin{array}{l}\text { 17-years old } \\
\text { Female (Proposita) } \\
\text { Consanguineous parents } \\
\text { (first cousins) } \\
\text { Ancestry: NR } \\
\text { Reported from Italy }\end{array}$ & $\begin{array}{l}\text { Palmar dermatoglyphics: } \\
\text { Bilateral transverse palmar creases, numerous } \\
\text { additional palmar creases (so-called "white lines"), } \\
\text { and ulnar displacement of t triradius }\end{array}$ \\
\hline $\begin{array}{l}\text { Scarano et al. } \\
1994[18]\end{array}$ & $\begin{array}{l}\text { Tel Hashomer camptodactyly } \\
\text { syndrome }\end{array}$ & $\begin{array}{l}\text { Age: NRA } \\
\text { Gender: NRA } \\
\text { Consanguinity: NRA } \\
\text { Ancestry: NRA } \\
\text { Reported from Italy }\end{array}$ & Dermatoglyphics NRA \\
\hline \multirow[t]{2}{*}{$\begin{array}{l}\text { Rogovina et al., } \\
1995 \text { [17] }\end{array}$} & $\begin{array}{l}\text { Tel Hashomer camptodactyly } \\
\text { syndrome }\end{array}$ & $\begin{array}{l}\text { Patient } 1 \text { (siblings) } \\
\text { Age, sex and ancestry NRA } \\
\text { Consanguinity: NRA } \\
\text { Reported from Russia }\end{array}$ & $\begin{array}{l}\text { Flexion folds between phalanges were absent } \\
\text { Other dermatoglyphic features NRA }\end{array}$ \\
\hline & & $\begin{array}{l}\text { Patient } 2 \text { (siblings) Age, sex and } \\
\text { ancestry NRA } \\
\text { Consanguinity: NRA } \\
\text { Reported from Russia }\end{array}$ & $\begin{array}{l}\text { Flexion folds between phalanges were absent } \\
\text { Other dermatoglyphic features NRA }\end{array}$ \\
\hline \multirow[t]{2}{*}{$\begin{array}{l}\text { Patel and Adhia } \\
2004[14]\end{array}$} & $\begin{array}{l}\text { Tel Hashomer camptodactyly } \\
\text { syndrome } \\
\text { Clinically diagnosed } \\
\text { Karyotype: } 46, X X \text {, chromosomal }\end{array}$ & $\begin{array}{l}\text { 30-years old } \\
\text { Female (Proposita) } \\
\text { No consanguinity } \\
\text { Ancestry: NR } \\
\text { Reported from India }\end{array}$ & Abnormal dermatoglyphics + \\
\hline & & $\begin{array}{l}\text { Age: NR } \\
\text { Female (sister) } \\
\text { No consanguinity } \\
\text { Ancestry: NR } \\
\text { Reported from India }\end{array}$ & Abnormal dermatoglyphics + \\
\hline $\begin{array}{l}\text { Melegh et al., } \\
2005[15]\end{array}$ & $\begin{array}{l}\text { Tel Hashomer camptodactyly } \\
\text { syndrome } \\
\text { Clinically diagnosed } \\
\text { Karyotype: normal }\end{array}$ & $\begin{array}{l}\text { 4-years old } \\
\text { Male (Proposita) } \\
\text { No consanguinity } \\
\text { Hungarian, followed up for } 12 \text { years } \\
\text { Reported from Hungary }\end{array}$ & $\begin{array}{l}\text { Digital dermatoglyphics: } \\
\text { Whorl patterns on all ten fingertips, } \\
\text { no other unusual ridges or flexion creases } \\
\text { Palmar dermatoglyphics: } \\
\text { No other unusual ridges or flexion creases were } \\
\text { seen on the fingers, palms, and soles }\end{array}$ \\
\hline
\end{tabular}


Table 1 Dermatoglyphic features of published cases of Tel Hashomer camptodactyly syndrome (Continued)

\begin{tabular}{|c|c|c|c|}
\hline \multirow[t]{2}{*}{$\begin{array}{l}\text { Smolkin et al., } \\
2011 \text { [5] }\end{array}$} & $\begin{array}{l}\text { Tel Hashomer camptodactyly } \\
\text { syndrome }\end{array}$ & $\begin{array}{l}\text { Twin } 1 \text { monochorionic biamniotic } \\
32 \text {-weeks 5-days old } \\
\text { Male } \\
\text { No consanguinity } \\
\text { Ancestry: NR } \\
\text { Reported from Israel }\end{array}$ & $\begin{array}{l}\text { Digital dermatoglyphics: } \\
\mathrm{RH}=\text { absent interphalangeal crease in finger } 5 \\
\mathrm{LH}=\text { absent interphalangeal crease in finger } 4,5 \\
\text { Palmar dermatoglyphics: } \\
\mathrm{RH}=\text { simian crease } \\
\mathrm{LH}=\text { simian crease } \\
\text { Partial absence of dermatoglyphic features }\end{array}$ \\
\hline & & $\begin{array}{l}\text { Twin } 1 \text { monochorionic biamniotic } \\
\text { 32-weeks 5-days old } \\
\text { Male } \\
\text { No consanguinity } \\
\text { Ancestry: NR } \\
\text { Reported from Israel }\end{array}$ & $\begin{array}{l}\text { Digital dermatoglyphics: } \\
\mathrm{RH}=\text { absent interphalangeal crease in finger } 2,3,4 \\
\mathrm{LH}=\text { absent interphalangeal crease in finger 2, 3,4, } \\
\text { Palmar dermatoglyphics: } \\
\mathrm{RH}=\text { simian crease } \\
\mathrm{LH}=\text { simian crease } \\
\text { Partial absence of dermatoglyphic features }\end{array}$ \\
\hline $\begin{array}{l}\text { Shah et al., } \\
2013 \text { [16] }\end{array}$ & $\begin{array}{l}\text { Tel Hashomer camptodactyly } \\
\text { syndrome }\end{array}$ & $\begin{array}{l}\text { 25-years old } \\
\text { Male (Proposita) } \\
\text { Consanguineous } \\
\text { Ancestry: NR } \\
\text { Reported from India }\end{array}$ & Dermatoglyphics not reported \\
\hline
\end{tabular}

$L H$ left hand, $M L I$ main line index, NR not reported, NRA not reported in abstract, $R C$ Ridge count, $R H$ right hand, TRC total ridge count, UL Ulnar loop

\section{Eligibility criteria and data extraction}

All studies that had diagnosed and reported THC syndrome were selected. From each, the following details were extracted: disease diagnosis, demographic details (age, sex, consanguinity, ancestry/lineage, country of case reported), and dermatoglyphic features. Initially, the full texts and abstract were screened and extracted by BTBW, and later SBA and RJM independently reviewed these studies for accuracy.

\section{Results}

The search of electronic databases yielded 14 publications. In addition, three publications were obtained from gray literature sources and hand searching the reference lists (Fig. 1). Full texts are available for 13 publications $[1,2,5-7,9-16]$, only an abstract was available for two publications $[17,18]$, and an abstract or full text was unavailable for another two $[19,20]$. Out of all 17 studies, only 14 publications were reviewed due to the unavailability of records for two publications $[19,20]$ and one publication reanalyzed a patient whose dermatoglyphics had been described previously [6].

There were 23 cases of THC described in the reviewed publications [6]. Six cases reported from Israel [1, 2, 5], three from Brazil $[9,12]$, three from India $[14,16]$, two from Italy $[13,18]$, three from Poland [10], one from the UK [11], two from the USA [7], two from Russia [17], and one from Hungary [15]. There were 11 females and nine males, and for three patients their sex was not reported in the available abstract $[17,18]$. All reported cases were among siblings or first-degree relatives. Eleven cases were born to consanguineous parents $[1,9,10,13,16]$ while nine were born to non- consanguineous parents $[2,5,11,12,14,15]$. Two cases did not report the consanguinity of their parents [7] and in three cases the consanguinity was not reported in the available abstract $[17,18]$. The dermatoglyphics were not reported in one case [16] and for another case dermatoglyphics were not reported in the abstract [18].

Key findings on dermatoglyphic features of the cases of THC are summarized in Table 1.

\section{Discussion}

Of the 21 cases that could be evaluated, eight reported whorls to be the most common digital pattern $[1,2,7,12$, 15]. Of particular interest, four of these were females with THC syndrome who had at least eight whorls [1, 2, 7, 12]. Conversely, normal males tend to have higher frequencies of whorl patterns [21]. As expected, there were also high average ridge counts, since whorls usually do have more ridges than loops and, of course, arches have zero ridge counts. It is also of interest to note that two of the cases, involving a sister/brother pair, had high frequencies of digital arch patterns with the brother having nine arches [9]. Usually, normal females tend to have more arches than males [21]. Furthermore, there frequently were an increased number of palmar creases than would normally be observed, along with abnormal flexion creases or other palmar dermatoglyphic abnormalities reported in all cases.

The fact that these cases appear to show some unusual results, for instance, in terms of digital patterns from unexpectedly high whorl frequency, especially in females with THC, to a very high number of arches, notably in males with THC, might indicate that there could have been some growth disturbances that took place during early fetal development at the time when epidermal ridges were being formed. In addition, unusual findings with respect to palmar dermatoglyphic features and flexion creases might well be indicative of abnormal developmental conditions. 
Of course, this intrauterine effect might well have occurred in association with the camptodactyly syndrome. Accordingly, it seems apparent that dermatoglyphic biomarkers may provide important clues when applying differential diagnoses, in conjunction with current molecular testing.

Therefore, it is important to thoroughly observe and record dermatoglyphic features when reporting future patients with THC syndrome, in addition to carrying out modern molecular methods. A highly beneficial consequence of this practice is that possible associations of dermatoglyphic biomarkers in genetically confirmed cases of THC could then be used as a relevant diagnostic aid in countries that have limited medical diagnostic resources.

\section{Abbreviation}

THC: Tel Hashomer camptodactyly

\section{Acknowledgements}

We acknowledge Dr Kosala Weerakoon for his support in retrieving the full text of some of the articles.

\section{Funding}

Not applicable.

\section{Availability of data and materials}

Not applicable.

\section{Authors' contributions}

BTBW conceived the idea. BTBW, RJM, and SBA were involved in study design, data analysis, drafting the article or revising it critically for important intellectual content, and all authors approved the final version.

\section{Competing interests}

All authors disclaim any financial or commercial involvement or other conflicts of interest.

\section{Consent for publication}

Not applicable.

\section{Ethics approval and consent to participate}

Not applicable.

\section{Author details}

'Department of Community Medicine, Faculty of Medicine and Allied Sciences, Rajarata University of Sri Lanka, Saliyapura 50008, Anuradhapura, Sri Lanka. ${ }^{2}$ Department of Anthropology, Indiana University, Bloomington, IN 47405, USA

Received: 29 June 2015 Accepted: 30 August 2016

Published online: 20 September 2016

\section{References}

1. Goodman RM, Katznelson MB, Hertz M, Katznelson A. Camptodactyly, with muscular hypoplasia, skeletal dysplasia, and abnormal palmar creases: Tel Hashomer camptodactyly syndrome. J Med Genet. 1976;13:136-41.

2. Goodman RM, Katznelson MB, Manor E. Camptodactyly: occurrence in two new genetic syndromes and its relationship to other syndromes. J Med Genet. 1972:9:203-12.

3. $\mathrm{OMIM}^{\oplus}$ Online Mendelian Inheritance in Man ${ }^{\oplus}$ [http://www.omim.org]. Accessed 12 May 2015

4. The portal for rare diseases and orphan drugs [http://www.orpha.net/ consor/cgi-bin/index.php]. Accessed 12 May 2015.

5. Smolkin T, Blazer S, Gershoni-Baruch R, Makhoul IR. Tel Hashomer camptodactyly syndrome in identical twin infants. Clin Dysmorphol. 2011;20:214-6.
6. Mochizuki A, Hyland J, Brown T, Slavin TP. Is Tel Hashomer camptodactyly a distinct clinical entity? Am J Med Genet Part A. 2015:167:255-8.

7. Toriello HV, Higgins JV, Malvitz T, Waterman DF. Two siblings with Tel Hashomer camptodactyly and mitral valve prolapse. Am J Med Genet. 1990;36:398-403.

8. Moher D, Liberati A, Tetzlaff J, Altman DG. Preferred reporting items for systematic reviews and meta-analyses: the PRISMA statement. PLoS Med. 2009:6:e1000097.

9. Gollop TR, Colletto GM. The Tel Hashomer camptodactyly syndrome in a consanguineous Brazilian family. Am J Med Genet. 1984;17:399-406.

10. Tylki-Szymanska A. Three new cases of Tel Hashomer camptodactyly syndrome in one Arabic family. Am J Med Genet. 1986;23:759-63.

11. Patton MA, McDermot KD, Lake BD, Baraitser M. Tel Hashomer camptodactyly syndrome: report of a case with myopathic features. J Med Genet. 1986;23:268-71.

12. Pagnan NA, Gollop TR, Lederman H. The Tel Hashomer camptodactyly syndrome: report of a new case and review of the literature. Am J Med Genet. 1988;29:411-7.

13. Franceschini P, Vardeu MP, Signorile F, Testa A, Guala A, Franceschini D, Dalforno L. Inguinal Hernia and Atrial Septal Defect in Tel Hashomer Camptodactyly Syndrome: Report of a New Case Expanding the Phenotypic Spectrum of the Disease. Am J Med Genet. 1993:46:341-4.

14. Patel ZM, Adhia RA. Tel-Hashomer camptodactyly syndrome with hirsuitism in an Indian family. J Assoc Physicians India. 2004;52(Oct):837-8.

15. Melegh B, Hollódy K, Aszmann M, Méhes K. Tel Hashomer camptodactyly syndrome: 12-Year follow-up of a Hungarian patient and review. Am J Med Genet. 2005;135(A):320-3.

16. Shah K, Sreekanth R, Thomas B, Danda S. Tel Hashomer Camptodactyly Syndrome. West Indian Med J. 2013;62:81-3.

17. Rogovina EG, Aver'ianov IN, Nechkina NP, Logunova LV. The Tel Hashomer Camptodactyly Syndrome. Zh Nevrol Psikhiatr Im S S Korsakova. 1995;95:83-6.

18. Scarano G, Della Monica M, Lonardo F, Police MA, D'vanzo MG. Sindrome di Tel Hashomer. Riv Ital Pediatr. 1994;20:572-5.

19. Verellen-Dumoulin C, De Meyer R, Brucher JM, Gengoux P, Lapiere CM, Kulakowski KS. Camptodactyly with muscular hypoplasia, skeletal dysplasia and abnormal palmar creases: a clinical genetic, morphological and dermatological study. In: Sixth Int Congr Hum Genet. Jerusalem. USA: A R Liss; 1981:258

20. Gollop T, Dal Colletto GM, Ferraretto I, Grimaldi A. New Manifestations Observed in the Tel Hashomer Camptodactyly Syndrome. Prog Clin Biol Res. 1982;104:269-77.

21. Cummins H, Midlo C. Finger Prints, Palms and Soles: An Introduction to Dermatoglyphics. New York: Dover Publications; 1961.

Submit your next manuscript to BioMed Central and we will help you at every step:

- We accept pre-submission inquiries

- Our selector tool helps you to find the most relevant journal

- We provide round the clock customer support

- Convenient online submission

- Thorough peer review

- Inclusion in PubMed and all major indexing services

- Maximum visibility for your research

Submit your manuscript at www.biomedcentral.com/submit 